Mirosław Pawlak

Zaktad Filologii Angielskiej, UAM Kalisz.

\title{
NAUCZANIE GRAMATYKI JĘZYKA OBCEGO - KIERUNKI I METODY BADAŃ
}

\section{Teaching foreign language grammar - research directions and methodological issues}

\begin{abstract}
Now that the value of grammar instruction has been corroborated in a number of studies, there is a need to determine the ways in which it should most beneficially be conducted. In order to do this, however, it is necessary to undertake empirical investigations which would address such issues as the choice of linguistic features to be taught, the effectiveness of specific techniques and procedures, the timing, duration and intensity of instruction, as well as its place in the overall curriculum. Since such research needs to be context-specific to provide a basis for practicable pedagogic proposals, the present paper outlines the main research directions and discusses key methodological issues in the area of form-focused instruction with a view to encouraging Polish applied linguists to pursue this line of inquiry.
\end{abstract}

\section{Wstęp}

Miejsce nauczania gramatyki w dydaktyce języka obcego zawsze budziło wiele kontrowersji i tak jest również obecnie, z tą różnica, że podstawową kwestią nie jest już to, czy ma ono sens, ale raczej to, w jaki sposób powinno się ono najskuteczniej odbywać. Z jednej strony, wyniki prowadzonych badań pokazały bardzo jednoznacznie, że położenie nacisku tylko i wyłącznie na komunikację, nawet w sytuacji częstego i trwającego przez wiele lat kontaktu z językiem docelowym, nie zapewnia równomiernego rozwoju wszystkich sprawności i podsystemów. $\mathrm{Z}$ drugiej natomiast, istnieje coraz więcej dowodów na to, że nauczanie struktur gramatycznych przynosi wymierne efekty i to nie tylko jeśli chodzi o poprawne stosowanie poznanych reguł w ćwiczeniach i testach, ale również umiejętność ich wykorzystania w celu przekazywania w miarę autentycznych treści i znaczeń, nawet 
dłuższy czas po tym, jak zostały wprowadzone i przećwiczone (patrz Doughty i Williams 1998; Ellis 2001a; Ellis 2006a; Pawlak 2006; Nassaji i Fotos 2007; Pawlak 2007a; Ellis 2008a; Spada i Lightbown 2008). Stąd też, teoretycy i badacze poszukuja obecnie najskuteczniejszych technik i procedur nauczania struktur gramatycznych, biorąc często pod uwage ich inherentne cechy, próbują ustalić kiedy, w jakiej kolejności i w jakich warunkach struktury te powinny pojawić się w programach nauczania, starają się ustalić wpływ czynników indywidualnych na skuteczność podejmowanych działań dydaktycznych i w końcu stawiają sobie za cel określenie roli przekonań, oczekiwań i procesów myślowych uczniów i nauczycieli w tym zakresie.

Trudno się chyba nie zgodzić, że osiągnięcie postępów we wszystkich tych obszarach ma ogromne znaczenie nie tylko dla specjalistów, którzy moga w ten sposób zweryfikować proponowane modele teoretyczne i zaproponować konkretne rozwiązania dydaktyczne, ale także dla praktyków, którzy moga na ich podstawie zoptymalizować nauczanie gramatyki w swoich klasach. Osiagnięcie tego celu wymaga jednak prowadzenia badań empirycznych w różnych kontekstach edukacyjnych, ponieważ tylko w ten sposób możliwa będzie weryfikacja przydatności postulowanych działań i upewnienie się, że są one dostosowane do lokalnych uwarunkowań. Takie badania są też bez wątpienia niezbędne na polskim gruncie, szczególnie w sytuacji, gdy gramatyka będzie z upływem czasu nieuchronnie marginalizowana w związku z obowiązującymi wymaganiami egzaminacyjnymi, a większość nauczycieli jest przekonana, że najskuteczniejszym sposobem jej opanowania jest wykonywanie dużej liczby tradycyjnych ćwiczeń. Niniejsza publikacja ma na celu wskazanie najważniejszych obszarów badawczych, którymi powinni się intensywniej zainteresować polscy językoznawcy stosowani jak również zwrócenie uwagi na kluczowe kwestie natury metodologicznej, o których należy pamiętać w pracach badawczych poświęconych nauczaniu gramatyki języka obcego.

\section{Główne kierunki badawcze}

Kierunki badań nad nauczaniem gramatyki języka obcego podlegały znacznym modyfikacjom na przestrzeni ostatnich kilkudziesięciu lat, przy czym dominującą tendencją jest stopniowe uszczegółowianie stawianych problemów, pytań i hipotez. Jak pisze Ellis (2001a), pierwsze projekty badawcze w tym obszarze można zakwalifikować do trzech podstawowych nurtów, tzn. badań porównujacych skutecznośc metod nauczania (ang. global method studies), badań porównawczych (ang. comparative studies) i badań opisujacych procesy zachodzqce w klasie jezykowej (ang. classroom process research). Te pierwsze były zazwyczaj przeprowadzane z ogromnych rozmachem na bardzo dużych próbach i miały przede wszystkim na celu ustalenie efektywności eksplicytnego (tj. świadomego) i implicytnego (tj. nieświadomego) podejścia do nauczania struktur gramatycznych (np. Smith 1970). Z kolei prace badawcze wpisujące się w drugi z wymienionych nurtów miały za zadanie 
porównanie finalnego poziomu opanowania języka przez osoby uczące się w klasie i w warunkach naturalnych, podejmując jednocześnie próbę oceny wpływu interwencji dydaktycznej na kolejność przyswajania określonych form języka oraz istnienie tzw. sekwencji rozwojowych (ang. orders and sequences of acquisition) (np. Pienemann 1984). Opracowania należące do ostatniego nurtu stawiały sobie za cel szczegółowy opis działań podejmowanych przez nauczycieli podczas lekcji, koncentrując się na różnych aspektach dyskursu klasowego, w szczególności na sposobach poprawiania błędów (np. Chaudron 1977). Wyniki tych trzech typów badań jasno pokazały, że nie jest możliwe jednoznaczne określenie najlepszej metody nauczania, interwencja skutkuje większą poprawnością użycia określonych struktur, ale nie prowadzi do zmiany zaprogramowanego w umyśle uczącego się sposobu ich przyswajania, i niezbędne jest zwrócenie uwagi nie tylko na osiagane przez uczniów wyniki, ale również na procesy zachodzące w klasie językowej (por. Ellis 1994, 2001; Pawlak 2006).

Wspomniane powyżej doprecyzowywanie pytań badawczych rozpoczęło się pod koniec lat osiemdziesiątych i na początku lat dziewięćdziesiątych ubiegłego wieku, kiedy to pojawiły się badania eksperymentalne zmierzające od ustalenia, czy nauczanie gramatyki prowadzi do opanowania określonych struktur, które przyniosły dalsze dowody na jego efektywność (np. Lightbown 1985; Day i Shapson 1991). Natomiast w ostatniej dekadzie daje się zaobserwować coraz silniejszy związek między prowadzonymi pracami badawczymi a wiodącymi modelami teoretycznymi, takimi jak teoria Pienemanna $(1985,1998)$ określająca kolejność przyswajania form języka w zależności od wymaganych operacji syntaktycznych, hipoteza interakcji (Long 1996), hipoteza produkcji językowej (Swain 1995), hipoteza świadomego postrzegania (Schmidt 1990, 2001), teoria przetwarzania danych językowych (Van Patten 1996, 2002) czy teoria uczenia się sprawności (DeKeyser 1998, 2001). Taki stan rzeczy spowodował, że kluczowym pytaniem nie jest obecnie to, çy nauczanie gramatyki przynosi efekty, bo sa na to przekonywujące dowody, ale to w jaki sposób powinno się ono odbywać, aby doprowadzić do przyswojenia określonych struktur (por. Ellis 2001a). Takie badania przyjmują najczęściej formę eksperymentu lub quasi-eksperymentu (ang. experimental i quasi-experimental study) i dotyczą następujących kwestii (Doughty i Williams 1998; Doughty 2001; Ellis 2001a; Nassaji i Fotos 2004; Williams 2005; Ellis 2006a; Nassaji i Fotos 2007; Pawlak 2007a; Ellis 2008a; Lightbown i Spada 2008):

- efektywność eksplicytnego i implicytnego nauczania gramatyki (np. Robinson 1996);

- porównanie skuteczności zwracania uwagi uczących się na określone formy językowe w trakcie wykonywania zadań komunikacyjnych z sytuacją, gdy koncentrują się oni jedynie na przekazywaniu treści i znaczeń (np. Williams i Evans 1998);

- rola podnoszenia świadomości metajęzykowej za pomocą różnego rodzaju zadań wymagających wspólnego odkrywania, omawiania i stosowania 
reguł i prawideł (ang. conscionsness-raising i dictogloss tasks) (np. Lapkin, Swain i Smith 2002; Piechurska-Kuciel 2005);

- efektywność dedukcyjnego i indukcyjnego nauczania gramatyki (np. Erlam 2003);

- wpływ technik mających na celu maksymalizację ekspozycji na określone struktury (ang. input flood) bądź też zwiększenie ich widoczności pośród danych językowych (ang. input enhamcement) na ich przyswojenie (Trahey 1996; Lee 2007; Lee i Huang 2008);

- porównanie efektywności nauczania opartego na recepcji i produkcji form językowych (np. Morgan-Short i Bowden 2006; Mystkowska-Wiertelak 2007);

- $\quad$ wpływ tradycyjnych opisów reguł i wyjaśnień opartych o gramatykę kognitywną na przyswajanie struktur gramatycznych (Bielak 2007);

- rola korekty błędów językowych w nauczaniu określonych form języka (np. Doughty i Varela 1998; Pawlak 2004; Mackey 2006);

- porównanie efektywności różnych rodzajów korekty błędów językowych w mowie (np. Ammar i Spada 2006; Ellis 2007) i piśmie (Sachs i Polio 2007; Bitchener i Knoch 2009);

- określenie efektywności różnych konfiguracji technik i procedur zwracających uwagę uczniów na określoną strukturę gramatyczną w trakcie wykonywania zadań komunikacyjnych (np. Pawlak 2006; Pietrzykowska 2008);

- porównanie skuteczności różnych sposobów planowania i organizacji zajęć w nauczaniu form językowych (np. Pawlak 2007).

Wiele z tych zagadnień było również przedmiotem badań opisowych (ang. descriptive studies), których liczba znacznie się w ostatniej dekadzie zwiększyła i które często stanowią uzupełnienie metodologii eksperymentalnej. Przede wszystkim, przeprowadzono wiele projektów badawczych, które miały na celu określenie możliwości integracji nauczania gramatyki z przekazywaniem treści podczas lekcji, zwracając szczególną uwagę na to, czy nacisk na formę języka odbywa się przed czy po popełnieniu błędu (ang. preemptive i reactive focus on form) (np. Ellis, Basturkmen i Loewen 2001; Loewen 2003; Majer 2003; Pawlak 2005; Lyster i Mori 2006; Loewen 2007). Ważnym uzupełnieniem tego nurtu, ale także badań eksperymentalnych poświęconych efektywności korekty, są wciąż jeszcze nieliczne prace, które uwzględniają interpretacje uczniów i nauczycieli (np. analiza nagrań fragmentów lekcji), co pozwala na pełniejsze zrozumienie, dlaczego pewne techniki są częściej używane i okazują się bardziej efektywne (np. Carpenter i in. 2006; Egi 2007). Prowadzone są również badania opisowe, które odwołują się do teorï socjokulturowej (Lantolf 2006) i, stosując charakterystyczne dla niej techniki analityczne, koncentrują się na procesie testowania hipotez i współtworzenia wiedzy językowej w dialogu pomiędzy uczniami (np. Swain i Lapkin 2007). Ciekawe są również opracowania poświęcone procesom myślowym nauczycieli (ang. teacher cognitions), które mają często charakter introspektywny i dotyczą przede wszystkich ich przekonań co do zasadności i sposobów nauczania gramatyki (np. Schultz 2001; Pawlak 
i Droździał-Szelest 2007) oraz decyzji, jakie podejmują w tym zakresie w trakcie lekcji (np. Basturkmen, Loewen i Ellis 2004; Borg 2006).

Zarówno wyniki badań eksperymentalnych, jak i opisowych jasno pokazały, że trudno jest określić efektywność nauczania gramatyki, niezależnie od tego, jakimi sposobami jest ono przeprowadzane, jeśli nie weźmiemy pod uwagę szeregu zmiennych moderujących, na co zwracają między innymi uwagę Norris i Ortega (2001). Chodzi tutaj w pierwszym rzędzie o różnice indywidualne, które powoduja, że te same techniki i procedury wcale nie muszą być tak samo przydatne w przypadku różnych osób. Choć czynniki indywidualne wciąż nieczęsto sa przedmiotem badań, daje się zaobserwować znaczący postęp w tym obszarze, szczególnie w odniesieniu do efektywności korekty błędów, o czym świadcza prace badawcze dotyczące roli wieku, zdolności językowych, inteligencji, pamięci roboczej, zdolności analitycznych czy płci (np. Skehan 1998; Robinson 2002; Ross-Feldman 2007; Sheen 2007; Trofimovich, Ammar i Gatbonton 2007). Na uwagę zasługuja też badania nad strategiami uczenia się gramatyki (np. Pawlak 2008a, 2009a), które pojawiły się dopiero w ostatnich kilku latach, lecz są niezwykle ważne, ponieważ mają szansę pokazać, w jaki sposób sami uczniowie moga usprawnić proces przyswajania tego podsystemu. Nie mniej istotne są właściwości nauczanej struktury, takie jak na przykład łatwość jej przyswojenia, czy to jako wiedzy eksplicytnej czy implicytnej, a zagadnienie to pojawiało się w badaniach, które przeprowadzili Robinson (1996), Housen, Vandaele i Pierrard (2005) i Ellis (2006b, 2008b). Warto także wspomnieć o opracowaniach dotyczących mniej zbadanych kwestii, związanych z czasem, długością i intensywnością interwencji dydaktycznej (np. Lightbown 1998; Pica 2007), włączeniem nauczania form języka do programów opartych o zadania komunikacyjne (Samuda 2001), wykorzystaniem wyników badań korpusowych (np. Barbieri i Eckhardt 2007) czy też sposobem prezentacji i ćwiczenia struktur gramatycznych w podręcznikach (np. Nitta i Gardner 2005; Michońska-Stadnik 2007).

Mimo że zakres studiów nad nauczaniem gramatyki jest doprawdy imponujący, wciąż wiemy bardzo mało na temat roli formalnej instrukcji oraz czynników determinujących jej skuteczność, między innymi dlatego, że wyniki projektów badawczych są fragmentaryczne i często ze sobą sprzeczne. Dlatego też niezbędne jest zintensyfikowanie badań w tym obszarze, które $z$ jednej strony wpisywałyby się w istniejące już nurty, a $\mathrm{z}$ drugiej wyznaczałyby zupełnie nowe kierunki i stawiały sobie coraz bardziej ambitne cele. Po pierwsze, istnieje wyraźna potrzeba replikacji wcześniejszych badań, nie tylko po to, aby dokonać weryfikacji ich wyników, ale także po to, aby uwzględnić kolejne języki obce, struktury gramatyczne i konteksty edukacyjne. Jest to o tyle ważne, że rezultaty prac badawczych prowadzonych w określonych uwarunkowaniach wcale nie muszą się sprawdzać w odmiennych sytuacjach, choćby dlatego, że nie uwzględniają one specyfiki danego kraju, różnic kulturowych czy też ograniczeń systemu edukacyjnego. Oznacza to, że również zalecenia dydaktyczne oparte o wyniki zagranicznych badań mogą się okazać mało skuteczne czy wręcz nierealne w polskim kontekście, co stanowi 
kolejny argument na rzecz podjęcia wysiłku replikacji (por. Pawlak 2006, 2007a). Jeśli chodzi o konkretne problemy badawcze, to jednym z najważniejszych wyzwań jest wyjaśnienie roli wiedzy eksplicytnej, rozumianej jako świadoma znajomość reguł gramatycznych w rozwoju wiedzy implicytnej, a więc takiej, która stanowi podstawę codziennej komunikacji i powinna być podstawowym celem dydaktyki językowej (por. Ellis 2006b). Cóż bowiem z tego, że uczniowie wykonają setki kolejnych tłumaczeń czy transformacji i dostaną dobre oceny na teście, jeśli nie będa potrafili wykorzystać swojej wiedzy w celu przekazywania ważnych dla nich treści w sytuacji, gdy ograniczone zasoby uwagi nie wystarczą, aby jednocześnie skupić się na formie i znaczeniu. Równie ważne jest określenie warunków, w których bardziej skuteczne jest produktywne i receptywne podejście do nauczania gramatyki, zweryfikowanie przydatności różnych form korekty błędów w trakcie wykonywania zadań komunikacyjnych, jak również opracowanie hierarchii trudności struktur gramatycznych w zależności od rodzaju wiedzy językowej.

Choć testowanie teorii i hipotez jest ważne, nie mniej istotne jest to, aby badania empiryczne pomagały nauczycielom rozwiązywać problemy, jakie napotykaja podczas nauczania struktur gramatycznych, co implikuje konieczność współpracy między teoretykami a praktykami, niezależnie od tego, czy będzie ona impulsem do badania eksperymentalnego, opisowego czy też badania w działaniu. Takie projekty badawcze powinny się koncentrować na określeniu efektywności konkretnych technik i ich rożnych konfiguracji, uwzględniając przy tym specyfikę nauczanych struktur, czynniki indywidualne, poziom edukacyjny, jak również inne zmienne warunkujące sukces w przyswajaniu gramatyki, o których pisze Pawlak (2009b). Mimo problemów metodologicznych, warto by się było pokusić o porównanie różnych sposobów planowania i organizacji nauczania struktur gramatycznych, tak na poziomie pojedynczych lekcji, ich sekwencji, a nawet całego programu nauczania. Ogromny potencjał tkwi też w badaniach nad przekonaniami i oczekiwaniami uczniów i ich nauczycieli, stopniem, w jakim znajdują one odzwierciedlenie podczas lekcji i ich wpływem na skuteczność nauczania (por. Pawlak 2007a). Zadziwiająco zaniedbanym obszarem jest też rola samych uczniów w przyswajaniu gramatyki, szczególnie jeśli chodzi o ich autonomię i podejmowane przez nich w tym zakresie działania strategiczne. Tę lukę należałoby jak najszybciej wypełnić, ponieważ badania nad strategiami uczenia się mogą zaowocować skutecznymi sposobami ich treningu, które stanowiłyby ważne uzupełnienie wypracowanych na podstawie wyników innych prac badawczych optymalnych technik nauczania gramatyki.

\section{Zagadnienia metodologiczne}

Podobnie jak w innych obszarach badań nad procesami zachodzacymi w klasie językowej, prace badawcze poświęcone nauczaniu gramatyki realizują dwa główne cele, tj. potwierdzenie teorii $i$ hipotez (ang. confirmatory research) bądź też interpretacje badanych zjawisk (ang. interpretative research) (por. Ellis 2001a). Do pierwszej grupy należą 
badania eksperymentalne (ang. experimental studies), które pozwalają określić wpływ interwencji dydaktycznej na poziom opanowania danej struktury, badania korelacyjne (ang. correlational studies), dzięki którym można na przykład ocenić relację między stosowaniem strategii uczenia się gramatyki a stopniem jej opanowania lub między różnymi sposobami instrukcji a czynnikami indywidualnymi, jak również badania porónnawcze (ang. comparative studies), które są używane w celu skontrastowania osiągnięć osób o różnych cechach czy różnych sposobów nauczania. Jeśli chodzi o druga grupę, można do niej zaliczyć badania opisowe (ang. descriptive studies), które koncentrują się na wypowiedziach uczących i nacisku na formę językowa podczas przekazywania znaczeń, a także badania introspektywne (ang. introspective studies), których głównym celem jest zgłębienie procesów myślowych uczniów i nauczycieli, w tym ich interpretacji technik nauczania. W ostatnich latach daje się zauważyć coraz częstsze próby połączenia tych na pozór zupełnie odmiennych tradycji badawczych i prowadzenia tzw. badan hybrydonych (ang. hybryd research), tak jak to się na przykład dzieje w studium Egi (2007), w którym zbadano efektywność przeformułowań w odniesieniu do sposobów ich interpretacji przez uczniów. Specjaliści podkreślają także wartość badań w działaniu (ang. action research), a to dlatego, że pozwalają one na zweryfikowanie różnych rozwiązań dydaktycznych podczas lekcji, a nie w wyidealizowanych warunkach (por. Ellis 1998). Ponieważ omówienie metodologii wszystkich wymienionych rodzajów badań wykracza poza ramy niniejszego opracowania, skupimy się tutaj jedynie na kwestii pomiaru wiedzy językowej, zagadnieniach związanych z planowaniem projektów badawczych oraz możliwościach wykorzystania nowoczesnych technologii.

Niezależnie od tego, czy mamy do czynienia z badaniami typowo eksperymentalnymi, quasi-eksperymentalnymi, opisowymi czy hybrydowymi, kluczowe znaczenie dla określenia efektywności instrukcji ma pomiar wiedsyy jeşykowej, tak aby można było ustalić początkowy i finalny stopień znajomości danej struktury (patrz Norris i Ortega 2001; Ellis 2001a; Norris i Ortega 2003). Jednym z mankamentów dostępnych badań eksperymentalnych jest to, że pomiar ten przeprowadzany jest na różne sposoby, co uniemożliwia dokonywanie rzetelnych porównań. Nie trzeba bowiem chyba nikogo przekonywać, że ten sam uczeń może wypaść lepiej lub gorzej, w zależności od tego, czy ma tylko ocenić poprawność gramatyczną zdania, wykazać, że rozumie znaczenie nauczanej struktury przez wybór odpowiedzi zgodnej z treścią tekstu, czy też ją poprawnie wyprodukować, przy czym w tym ostatnim przypadku należy się spodziewać kolosalnych różnic między wynikami ćwiczeń gramatycznych i zadań komunikacyjnych. O wiele groźniejszym zjawiskiem jest jednak to, że w wielu badaniach empirycznych wciąż nie uwzględnia się wspomnianego już wyżej rozróżnienia między świadomą wiedzą eksplicytną a nieświadomą wiedzą implicytną. Oznacza to, że efektywność instrukcji jest oceniana jedynie na podstawie wyników tradycyjnych testów, a nie umiejętności zastosowania danej struktury w komunikacji, co uniemożliwia wiarygodną ocenę stopnia jej przyswojenia. Co gorsza, nawet jeśli badacze podejmują próbę pomiaru wiedzy implicytnej, to dobór używanych w tym celu zadań często budzi 
wątpliwości, bo jeśli na przykład uczeń ma utworzyć zdania na temat obrazka na podstawie podanych wskazówek, to przecież w pełni uprawnione będzie stwierdzenie, że może tego dokonać w sposób świadomy, wykorzystując zautomatyzowaną wiedzę eksplicytną. Natomiast w badaniach o charakterze opisowym najczęściej używanym kryterium skuteczności interwencji dydaktycznej jest skuteczne przejecie informacji zwrotnej (ang. successful uptake), głównie w postaci autokorekty (por. Lyster i Ranta 1997). Choć reakcja ta często następuje w trakcie przekazywania w miarę autentycznych treści, to nie da się na tej podstawie ustalić, czy zaobserwowany pozytywny efekt interwencji będzie długotrwały, a z kolei brak pożądanej reakcji nie oznacza, że informacja zwrotna nie została zarejestrowana i nie zostanie później wykorzystana w celu modyfikacji języka pośredniego. Takie trudności pokazuja, że nawet w przypadku badań eksploracyjnych jest potrzebne uzupełnienie analizy nagrań bardziej zobiektywizowanymi i rzetelnymi narzędziami pomiaru.

Podstawowym powodem, dla którego w wielu pracach badawczych poprzestaje się na ocenie skuteczności interwencji przez pryzmat wyników testów pisemnych jest to, że pomiar wiedzy implicytnej nie jest łatwym zadaniem. Oczywiście najlepszym rozwiązaniem byłoby zaplanowanie zadań komunikacyjnych, których poprawne wykonanie nie byłoby możliwe bez użycia określonej struktury, ale napotykamy tutaj szereg problemów, bo uczestnicy badania moga stosować strategię uniku i osiagnąć wymagane cele przy wykorzystaniu alternatywnych środków językowych (por. Loschky i Bley-Vroman 1993). Oczywiście nie oznacza to, że nie da się takich aktywności skonstruować przy użyciu odpowiednich przykładów, wskazówek czy języka ojczystego (np. Pawlak 2004, 2006), ale zawsze pozostają wattpliwości co do rodzaju wykorzystywanej wiedzy językowej, a pewne struktury będą nastręczać więcej problemów niż inne. Dlatego też w ostatnich latach podejmowane są wysiłki na rzecz opracowania trafnych i rzetelnych narzędzi pomiaru wiedzy eksplicytnej i implicytnej oraz ich zastosowania w celu stworzenia hierarchii trudności struktur gramatycznych (np. Ellis 2005, 2006; Erlam 2006; Ellis 2008b). I tak, Ellis (2005) proponuje, aby pomiar wiedzy eksplicytnej odbywał się przy pomocy testu na ocenę poprawności gramatycznej zdań oraz testu wiedzy metajęzykowej, z których żaden nie podlegałby ograniczeniom czasowym. Do pomiaru wiedzy implicytnej można natomiast wykorzystać test na ocenę poprawności zdań wykonywany w ściśle określonych ramach czasowych, opowiadanie, w którym uczący się streszczają przeczytany tekst w ciagu trzech minut oraz test na imitację, w którym muszą najpierw zdecydować, czy zgadzają się z podanymi stwierdzeniami, a następnie poprawnie je powtórzyć mimo, że połowa z nich zawiera błąd. Choć takie zadania na pewno nie zastąpią zadań komunikacyjnych wymagających użycia określonej struktury, na pewno moga być ich ważnym uzupełnieniem i umożliwiać weryfikację uzyskanych wyników. Ich zaletą jest też to, że pozwalają na pomiar obu rodzajów wiedzy w wymiarze produktywnym i receptywnym, co jest o tyle ważne, że uczeń może bez problemu zrozumieć znaczenie danej formy językowej podczas rozmowy, ale nie będzie w stanie jej poprawnie wyprodukować. 
Równie ważne jak zastosowanie odpowiednich narzędzi pomiaru wiedzy językowej jest poprawne zaplanowanie projektu badawczego, zmierzającego do oceny efektywności technik i procedur nauczania gramatyki. Mimo że możliwe jest przeprowadzenie tzw. badania przedeksperymentalnego (ang. pre-experimental study), w którym przydatność interwencji dydaktycznej określana jest w jednej tylko grupie, nie pozwala ono jednoznacznie ustalić związków przyczynowo-skutkowych i ma jedynie wstępny charakter, stanowiąc punkt wyjścia do badań eksperymentalnych i quasi-eksperymentalnych (por. Larsen-Freeman i Long 1991). W studiach nad uczeniem się i nauczaniem języka obcego dominują te drugie, jako że często nie jest możliwy losowy przydział badanych do poszczególnych grup i konieczne jest dokonywanie porównań między klasami czy grupami funkcjonującymi na co dzień w danej instytucji edukacyjnej (patrz Dörnyei 2007). Tym niemniej, tak jak $\mathrm{w}$ innych eksperymentach, niezbędne jest wyłonienie grupy kontrolnej, przeprowadzenie testów przed i po interwencji oraz zastosowanie odpowiednich narzędzi statystyki inferencyjnej. Kwestią o kluczowym znaczeniu jest również upewnienie się, że zaobserwowane efekty mają charakter trwały i stopniowo nie znikna kilka dni czy tygodni po zakończeniu instrukcji lub że nie przyniesie ona wymiernych rezultatów dopiero po pewnym czasie. Oznacza to, że potrzebne jest przeprowadzanie nie tylko testu wstepnego (ang. pretest) i końcowego (ang. immediate posttest), co pozwoli ocenić natychmiastowe postępy uczniów, ale także przynajmniej jednego testu dystansowego (ang. delayed posttest), który pokaże, jak wygląda poziom opanowania nauczanych struktur po upływie pewnego czasu. Inną zaletą takiego rozwiązania jest to, że umożliwia ono połączenie badan poprzecżnych (ang. crosssectional studies) z badaniami podtuingmimi (ang. longitudinal studies), a to pozwala na systematyczne śledzenie procesu przyswajania danej struktury (por. Doughty 2003). Trzeba też pamiętać, że interwencja ograniczona do jednej czy dwóch lekcji to często zbyt mało, aby można było zaobserwować wymierne efekty, konieczna jest jej precyzyjna operacjonalizacja, bo inaczej trudno będzie jednoznacznie określić przyczynę postępów, a stosowane narzędzia pomiarowe powinny być przetestowane, co pozwoli określić ich rzetelność i trafność. Warto na koniec zauważyć, że wiarygodność wyników wzrośnie, jeśli uzupełnimy metodologię eksperymentalną metodologią opisowa, ponieważ pozwoli nam to zweryfikować poprawność przeprowadzenia interwencji oraz zinterpretować jej efekty w odniesieniu do przekonań, oczekiwań i decyzji uczniów i nauczycieli. Może się na przykład okazać, że niewielkie różnice pomiędzy grupą eksperymentalną i kontrolną wcale nie są wynikiem małej skuteczności określonej techniki, ale tego, że nauczyciel mimowolnie zwrócił uwagę uczniów na daną strukturę, co spowodowało, że postanowili ją samodzielnie przećwiczyć w domu. Identyfikacja takiej dodatkowej zmiennej nie jest jednak możliwa, jeśli skoncentrujemy się wyłącznie na interwencji i wynikach testów, ponieważ wymaga ona zastosowania takich narzędzi jak obserwacja zajęć, wywiady czy kwestionariusze.

$\mathrm{Na}$ zakończenie warto zwrócić uwagę na możliwości zastosowania nowoczesnych technologii w badaniach nad nauczaniem gramatyki. Po pierwsze in- 
terwencja dydaktyczna, niezależnie od jej charakteru, może się odbywać przy pomocy komputera, czego dowodzą między innymi badania, które przeprowadzili Lee i Benati (2007) w odniesieniu do receptywnego podejścia do nauczania gramatyki oraz Sachs i Suh (2007) i Sagarra (2007) w celu oceny efektywności przeformułowań. Wykorzystanie technologii komputerowej umożliwia też nieporównywalnie bardziej precyzyjny pomiar wiedzy językowej, ponieważ łatwo można ustalić, jak długo dane zdanie będzie widoczne na ekranie, co ma kluczowe znaczenie, kiedy ocena jego poprawności ma na celu ocenę stopnia przyswojenia struktury jako wiedzy implicytnej. Ogromny potencjał mają również najnowsze odkrycia w neurolingiwstyce, gdyż zastosowanie takich technik jak elektroencefalografia czy funkcjonalny rezonans magnetyczny może rzucić nowe światło na relacje pomiędzy wiedzą eksplicytną i implicytną oraz skuteczność poszczególnych sposobów nauczania (patrz N. Ellis 2007). Choć zastosowanie tak zaawansowanej technologii jest wciąż zbyt kosztowne i nie jest ona szeroko dostępna, wydaje się, że jej częstsze wykorzystanie w pracach badawczych nad uczeniem się i nauczaniem gramatyki jest tylko kwestią czasu.

\section{Zakończenie}

W obliczu obowiązujących wymagań egzaminacyjnych, które kładą nacisk na umiejętność osiagania autentycznych celów komunikacyjnych, przywiązując jednocześnie małą wagę do poprawności językowej, niezbędne wydaje się opracowanie nowego modelu wprowadzania i ćwiczenia gramatyki w polskich szkołach. Z jednej bowiem strony nie można dopuścić, aby nauczanie tego ważnego podsystemu zostało zepchnięte na margines dydaktyki językowej, ale $z$ drugiej trzeba mieć świadomość, że praktykowane przez wielu nauczycieli podejście, w którym nie ma miejsca na używanie poznanych struktur w komunikacji jest mało przydatne i donikąd nie prowadzi. Poszukując optymalnych rozwiązań nie można jednak bezkrytycznie akceptować zaleceń proponowanych w oparciu o wyniki badań empirycznych prowadzonych za granica, jako że w wielu przypadkach nie uwzględniaja one specyfiki polskiego kontekstu edukacyjnego, sa przez to mało skuteczne i nie przystają do istniejących uwarunkowań i ograniczeń. W związku z tym niezbędne jest prowadzenie badań nad skutecznymi sposobami nauczania gramatyki na rodzimym gruncie, tym bardziej, że obecnie problematyka ta jest zbyt rzadko podejmowana, a nawet jeśli pojawiają się opracowania jej poświęcone, to nieczęsto uwzględniają one najnowsze trendy. Wychodząc naprzeciw tej potrzebie, niniejszy artykuł miał na celu zaprezentowanie aktualnych kierunków badań empirycznych dotyczących nauczania gramatyki, jak również zwrócenie uwagi na ważne zagadnienia metodologiczne, które w dużej mierze determinują wartość takich przedsięwzięć. Jedynie bowiem dobrze zaplanowane projekty badawcze, które uwzględniają zarówno dotychczasowe osiagnięcia, jak i lokalną specyfikę dają nadzieję na wypracowanie optymalnych rozwiązań dydaktycznych, tak w doniesieniu do nauczania gramatyki, jak i innych podsystemów i sprawności. 


\section{BIBLIOGRAFIA}

Ammar, A. i Spada, N. 2006. „Recasts, prompts and L2 learning”. Studies in Second Language Acquisition 28. 543-574.

Barbieri, F. i Eckhardt, S. 2007. „Applying corpus-based findings to formfocused instruction: The case of reported speech". Language Teaching Research 11. 347-372.

Barker, A., Callahan, D. i Ferreira, M. A. (red.). 2009. Success and failure. Aveiro: University of Aveiro Press.

Basturkmen, H., Loewen, S. i Ellis, R. 2004. „Teachers' stated beliefs about incidental focus on form and their classroom practices". Applied Linguistics 25. 243-272.

Bielak, J. 2007c. „Applying Cognitive Grammar in the classroom: Teaching English possessives", w: Pawlak, M. (red.). 2007b. 113-134.

Bitchener, J. i Knoch, U. 2009. „The relative effectiveness of different types of direct written corrective feedback". System 37. 322-329.

Borg, S. 2006. Teacher cognition and language education: Research and practice. London: Continuum.

Bygate, M., Skehan, P. i Swain, M. (red.). 2001. Researching pedagogic tasks: Second language learning, teaching and testing. Harlow: Pearson Education.

Carpenter, H., Jeon, S. K., MacGregor, D. i Mackey, A. 2006. „Learner's interpretation of recasts". Studies in Second Language Acquisition 209-236.

Chaudron, C. 1977. „A descriptive model of discourse in the corrective treatment of learners' errors". Language Learning 27. 29-46.

Cook, G. i Seidlhofer, B. (red.). 1995. Principles and practice in applied linguistics: Studies in honor of H. G. Widdowson. Oxford: Oxford University Press.

Crookes, G. i Gass, S. (red.). 1993. Tasks and language learning. Vol. 1. Clevedon, Avon: Multilingual Matters.

Day, E. M. i Shapson, S. M. 1991. „Integrating formal and functional approaches to language teaching in French immersion: An experimental study". Language Learning 41. 25-58.

DeKeyser, R. M. 1998. „Beyond focus on form: Cognitive perspectives on learning and practicing second language grammar", w: Doughty, C. i Williams, J. (red.). 1998. 42-63.

DeKeyser, R. M. 2001. „Automaticity and automatization”, w: Robinson, P. (red.). 2001. 125-151.

Doughty, C. 2001. „Cognitive underpinnings of focus on form”, w: Robinson, P. (red.). 2001. 206-257.

Doughty, C. 2003. „Instructed SLA: Constraints, compensation and enhancement", w: Doughty, C. i Long, M. H. (red.). 2003. 256-310.

Doughty, C. i Long, M. H. (red.). 2003. The handbook of second language acquisition. Malden, MA: Blackwell.

Doughty, C. i Varela, E. 1998. „Communicative focus on form”, w: Doughty, C. i Williams, J. (red.). 1998. 114-138. 
Doughty, C. i Williams, J. (red.). 1998. Focus on form in classroom second language acquisition. Cambridge: Cambridge University Press.

Dörnyei, Z. 2007. Research methods in applied linguistics. Oxford: Oxford University Press.

Egi, T. 2007. „Recasts, learners’ interpretations, and L2 development”, w: Mackey, A. (red.). 2007. 249-267.

Ellis, N. 2007. „The weak interface, consciousness, and form-focused instruction: Mind the doors", w: Fotos, S. i Nassaji, H. (red.). 2007. 17-34.

Ellis, R. 1998. „Teaching and research: Options in grammar teaching”. TESOL Quarterly 32. 39-60.

Ellis, R. 2001a. „Introduction: Investigating form-focused instruction”, w: Ellis, R. (red.). 2001b. 1-46.

Ellis, R. (red.). 2001b. Form-focused instruction and second language learning. Oxford: Blackwell Publishers.

Ellis, R. 2005. „Measuring implicit and explicit knowledge of a second language: A psychometric study". Studies in Second Language Acquisition 27. 141-172.

Ellis, R. 2006a. „Current issues in the teaching of grammar: An SLA perspective”. TESOL Quarterly 40. 83-107.

Ellis, R. 2006b. „Modeling learning difficulty and second language proficiency: The differential contributions of implicit and explicit knowledge". Applied Linguistics 27. 431-463.

Ellis, R. 2007. „The differential effects of corrective feedback on two grammatical structures", w: Mackey, A. (red.). 2007. 339-360.

Ellis, R. 2008a. The study of second language acquisition. (wydanie drugie). Oxford: Oxford University Press.

Ellis, R. 2008b. „Investigating grammatical difficulty in second language learning: Implications for second language acquisition research and language testing". International Journal of Applied Linguistics 18. 4-22.

Ellis, R., Basturkmen, H. i Loewen, S. 2001. „Learner uptake in communicative ESL lessons". Language Learning 51. 281-318.

Erlam, R. 2003. „The effects of deductive and inductive instruction on the acquisition of direct object pronouns in French as a second language". Modern Language Journal 87. 242-260.

Erlam, R. 2006. „Elicited imitation as a measure of L2 implicit knowledge: An empirical validation study". Applied Linguistics 27. 464-491.

Fotos, S. i Nassaji, H. 2007. (red.). Form-focused instruction and teacher education: Studies in honor of Rod Ellis. Oxford: Oxford University Press.

Hinkel, E. (red.). 2005. Handbook of research in second language teaching and learning. Mahwah, NJ: Lawrence Erlbaum.

Housen, A. i Pierrard, M. (red.). 2005. Investigations in instructed second language acquisition. Berlin-New York: Mouton de Gruyter.

Housen, A., Pierrard, M. i Vandaele, S. 2005. „Structure complexity and the efficacy of explicit grammar instruction", w: Housen, A. i Pierrard, M. (red.). 2005. 235-269. 
Hyltenstam, K. i Pienemann, M. (red.). 1985. Modeling and assessing second language acquisition. Clevedon, Avon: Multilingual Matters.

Lantolf, J. 2006. „Sociocultural Theory and L2: State of the art”. Studies in Second Language Acquisition 28. 67-109.

Lapkin, S, Swain, M. i Smith, M. 2002. „Reformulation and the learning of French pronominal verbs in a Canadian French immersion context". Modern Language Journal 86. 485-507.

Larsen-Freeman, D. i Long, M. H. 1991. An introduction to second language acquisition research. London: Longman.

Lee, J. F. i Benati, A. G. 2007. Delivering processing instruction in classrooms and virtual contexts. London: Equinox.

Lee, S. -K. 2007. „Effects of textual enhancement and topic familiarity on Korean EFL students' reading comprehension and learning of passive form". Language Learning 57. 87-118.

Lee, S. -K. i Huang, H. -T. 2008. „Visual input enhancement and grammar learning: A meta-analytic review". Studies in Second Language Acquisition 30. 307-331.

Lightbown, P. 1985. „Can language acquisition be altered by instruction?”, w: Hyltenstam, K. i Pienemann, M. (red.). 1985. 101-112.

Lightbown, P. 1998. ,The importance of timing in focus on form”, w: Doughty, C. i Williams, J. (red.). 1998c. 177-196.

Loewen, S. 2003. „Variation in the frequency and characteristics of incidental focus of form". Language Teaching Research 7. 315-346.

Loewen, S. 2007. „The prior and subsequent use of forms targeted in incidental focus on form", w: Fotos, S. i Nassaji, H. (red). 2007. 101-116.

Long, M. H. 1996. „The role of the linguistic environment in second language acquisition", w: Ritchie, W. i Bhatia, T. (red.). 1996. 413-468.

Loschky, L. i Bley-Vroman, R. 1993. „Grammar and task-based methodology”, w: Crookes, G. i Gass, S. (red.). 1993. 123-167.

Lyster, R. i Mori, H. 2006. „Interactional feedback and instructional counterbalance". Studies in Second Language Acquisition 28. 269-300.

Lyster, R. and Ranta, L. 1997. „Corrective feedback and learner uptake: Negotiation of form in communicative classrooms". Studies in Second Language Acquisition 19. 37-66.

Mackey, A. 2006. „Feedback, noticing and instructed second language learning”. Applied Linguistics 27. 405-430.

Mackey, A. (red.). 2007. Conversational interaction in second language acquisition. Oxford: Oxford University Press.

Majer, J. 2003. Interactive discourse in the foreign language classroom. Lódź: Wydawnictwo Uniwersytetu Lódzkiego.

Michońska-Stadnik, A. 2007. „Presentation and practice of grammatical items in selected English language teaching coursebooks", w: Pawlak, M. (red.). 2007c. 319-329. 
Morgan-Short, K. i Bowden, H. W. 2006. „Processing instruction and meaningful output-based instruction: Effects on second language development”. Studies in Second Language Acquisition 28. 31-65.

Mystkowska-Wiertelak, A. 2007. "The effectiveness of interpretation tasks in teaching inversion to advanced learners of English”, w: Pawlak, M. (red.). 2007c. 155-167.

Nassaji, H. i Fotos, S. 2007. „Issues in form-focused instruction and teacher education", w: Fotos, S. and Nassaji, H. (red). 2007. 7-15.

Nassaji, H. i Fotos, S. 2004. „Current developments in the teaching of grammar”. Annual Review of Applied Linguistics 24. 126-145.

Nitta, R. i Gardner, S. 2005. „Consciousness-raising and practice in ELT coursebooks". ELT Journal 56. 3-13.

Norris, J. M. i Ortega, L. 2001. „Does type of instruction make a difference? Substantive findings from a meta-analytic review", w: Ellis, R. (red.). 2001b. $157-213$.

Norris, J. M. i Ortega, L. 2003. „Defining and measuring SLA”, w: Doughty, C. i Long, M. H. (red.). 2003. 717-761.

Pawlak, M. 2004. „On helping students be more accurate. Can the mission ever be accomplished?". LATEFL Research News 14. 24-28.

Pawlak, M. 2005. ,The feasibility of integrating form and meaning in the language classroom: A qualitative study of classroom discourse". Glottodidactica 3031. 283-294.

Pawlak, M. 2006. The place of form-focused instruction in the foreign language classroom. Poznań - Kalisz: Wydawnictwo Wydziału Pedagogiczno-Artystycznego UAM.

Pawlak, M. 2007a. „An overview of focus on form in language teaching”, w: Pawlak, M. (red.). 2007c. 5-26.

Pawlak, M. 2007b. „Comparing the effect of focus on form and focus on forms in teaching English third conditional”, w: Pawlak, M. (red.). 2007c. 169-192.

Pawlak, M. (red.). 2007c. Exploring focus on form in language teaching. [Special issue of Studies in Pedagogy and Fine Arts Vol. VII. Poznań - Kalisz: Wydawnictwo Wydziału Pedagogiczno-Artystycznego UAM.

Pawlak, M. i Droździał-Szelest, K. 2007. „When I think about grammar... Exploring English Department students' beliefs about grammar, grammar learning and grammar teaching", w: Pawlak, M. (red). 2007c. 299-318.

Pawlak, M. 2008a. „Advanced learners' use of strategies for learning grammar: A diary study", w: Pawlak, M. (ed.). 2008b. 109-125.

Pawlak, M. (red.). 2008b. Investigating English language learning and teaching. Poznań - Kalisz: Wydawnictwo Wydziału Pedagogiczno-Artystycznego UAM.

Pawlak, M. 2009a. „Instructional mode and the use of grammar learning strategies”, w: Pawlak, M. (red.). 2009c. 267-290.

Pawlak, M. 2009b. „Factors influencing success and failure in the learning of grammar", w: Barker, A., Callahan, D. i Ferreira, M. A. (red.). 2009. 327-338. 
Pawlak, M. 2009c. (red.). New perspectives on individual differences in language learning and teaching. [Special issue of Studies in Pedagogy and Fine Arts Vol. VIII]. Poznań - Kalisz: Wydawnictwo Wydziału Pedagogiczno-Artystycznego UAM.

Pica, T. 2007. „Time, teachers and tasks”, w: Fotos, S. i Nassaji, H. (red.). 2007. $161-175$.

Piechurska-Kuciel, E. 2005. The importance of being aware: Advantages of explicit grammar study. Opole: Opole University Press.

Pienemann, M. 1984. „Psychological constraints on the teachability of languages”. Studies in Second Language Acquisition 11. 63-90.

Pienemann, M. 1985. „Learnability and syllabus construction”, w: Hyltenstam, K. i Pienemann, M. (red.). 1985. 23-76.

Pienemann, M. 1998. Language processing and second language development: Processability theory. Amsterdam-Philadelphia: John Benjamins.

Pietrzykowska, A. 2008. ,The effectiveness of focus on forms vs. focus on form in teaching English quantifiers", w: Pawlak, M. (red.). 2008b. 149-157.

Ritchie, W. i Bhatia, T. (red.). 1996. Handbook of research on second language acquisition. New York: Academic Press.

Robinson, P. 1996. „Learning simple and complex second language rules under implicit, incidental, rule-search, and instructed conditions". Studies in Second Language Acquisition 18. 27-68.

Robinson, P. (red.). 2001. Cognition and second language instruction. Cambridge: Cambridge University Press.

Robinson, P. (red.). 2002. Individual differences and instructed language learning. Amsterdam - Philadelphia: John Benjamins.

Ross-Feldman, L. 2007. „Interaction in the L2 classroom: Does gender influence learning opportunities?", w: Mackey, A. (red.). 2007. 53-77.

Samuda, V. 2001. „Guiding relationships between form and meaning during task performance: The role of the teacher", w: Bygate, M., Skehan, P. i Swain, M. (red.). 2001. 119-140.

Sachs, R. i Polio, C. 2007. „Learners' uses of two types of written feedback on a L2 writing revision task". Studies in Second Language Acquisition 29. 67-100.

Sachs, R. i Suh, B. -R. 2007. „Textually enhanced recasts, learner awareness, and L2 outcomes in synchronous computer-mediated interaction", w: Mackey, A. (red.). 2007. 197-227.

Sagarra, N. 2007. „From CALL to face-to-face interaction: The effect of computerdelivered recasts and working memory on L2 development", w: Mackey, A. (red.). 2007. 229-248

Schmidt, R. 1990. „The role of consciousness in second language learning”. Applied Linguistics 11. 17-46.

Schmidt, R. 2001. „Attention”, w: Robinson, P. (red.). 2001. 3-32.

Schultz, R. 2001. „Cultural differences in student and teacher perceptions concerning the role of grammar teaching and corrective feedback". Modern Language Journal 85. 244-258. 
Sheen, Y. 2007. ,'The effect of focused written corrective feedback and language aptitude on ESL learners' acquisition of articles”. TESOL Quarterly 41. 255-283.

Skehan, P. 1998. A cognitive approach to language learning. Oxford: Oxford University Press.

Smith, P. 1970. A comparison of the cognitive and audiolingual approaches to foreign language instruction: The Pennsylvania Foreign Language Project. Philadelphia: Center for Curriculum Development.

Spada, N. i Lightbown, P. 2008. „Form-focused instruction: Isolated or integrated?". TESOL Quarterly 42. 181-207.

Swain, M. 1995. „Three functions of output in second language learning”, w: Cook, G. i Seidlhofer, B. (red.). 1995. 125-144.

Swain, M. i Lapkin, S. 2007. ,"The distributed nature of second language learning: Neil's perspective", w: Fotos, S. i Nassaji, H. (red.). 2007. 73-86.

Trahey, M. 1996. „Positive evidence in second language acquisition: Some longterm effects". Second Language Research 12. 11-139.

Trofimovich, P., Ammar, A. i Gatbonton, E. 2007. „How effective are recasts? The role of attention, memory, and analytical ability", w: Mackey, A. (red.). 2007. 171-195.

VanPatten, B. 1996. Input processing and grammar instruction. Norwood, NJ: Ablex Publishing Corporation.

VanPatten, B. 2002. „Processing instruction: An update”. Language Learning 52. 755-804.

Williams, J. 2005. „Form-focused instruction”, w: Hinkel, E. (red.). 2005. 671-691.

Williams, J. i Evans, J. 1998. „What kind of focus on which forms?”, w: Doughty, C. i Williams, J. (red.). 1998. 139-155. 